\title{
Combining Modified Atmosphere Packaging and Nisin to Preserve Atlantic Salmon
}

\author{
Dong Han ${ }^{1}$, Inyee $\mathrm{Han}^{2} \&$ Paul Dawson ${ }^{2}$ \\ ${ }^{1}$ Auburn University, Auburn, AL, USA \\ ${ }^{2}$ Department of Food, Nutrition and Packaging Sciences, Clemson University, Clemson, SC, USA \\ Correspondence: Paul Dawson, Department of Food, Nutrition and Packaging Sciences, Clemson University, \\ Clemson, SC 29634, USA. Tel: 864-656-1138. E-mail: pdawson@clemson.edu
}

Technical Contribution No. 6460 of the Clemson University Experiment Station.

Received: September 3, 2016

Accepted: November 16, $2016 \quad$ Online Published: December 8, 2016

doi:10.5539/jfr.v6n1p22

URL: http://dx.doi.org/10.5539/jfr.v6n1p22

\begin{abstract}
Preservation effects of modified atmosphere package combined with nisin on fresh Atlantic salmon were evaluated. Farm-raised Atlantic salmon were purchased from the local market and packaged using either $19 \%$ $\mathrm{CO}_{2}: 70 \% \mathrm{~N}_{2}: 11 \% \mathrm{O}_{2}, 38 \% \mathrm{CO}_{2}: 51 \% \mathrm{~N}_{2}: 11 \% \mathrm{O}_{2}$, and under atmospheric air (with and without nisin at $400 \mathrm{IU} / \mathrm{g}$ ) resulting in a total of 6 treatments. The microbiological (aerobic plate count, psychrotrophic bacteria, and lactic acid bacteria) and the total volatile basic nitrogen analyses were evaluated on Day 0, 2, 4, 7 and 10. Package headspace and sensory evaluation were also conducted on Day 0,2 and 4. The presence of $\mathrm{CO}_{2}$ effectively inhibited the growth of all three types of bacteria while nisin significantly inhibited the growth of aerobic microorganisms with less impact on lactic acid bacteria. The TVB-N test indicated that $\mathrm{CO}_{2}$ delayed the spoilage of Atlantic salmon while nisin had a lesser but measurable impact on Atlantic salmon shelf-life. The experiments support the potential for combining modified atmosphere package and nisin as an effective method to limit the spoilage of Atlantic salmon compare to traditional preservation methods.
\end{abstract}

Keywords: Atlantic salmon, modified atmosphere packaging, nisin, shelf life

\section{Introduction}

Modified atmosphere packaging (MAP) has become a popular preservation technology (McMillin, 2008). The basis of MAP is a sealed food package with an altered headspace gas mixture. Both microbiological and chemical reactions continue during shipping and storage often altering the package gas headspace. Several researchers (Fagan et al., 2004; Wang et al., 2008; Economou et al., 2009; Tsironi et al., 2010) have studied the effect of the MAP on fresh seafood product shelf life. Other researchers (Jayasingh, et al., 2002; Sivertsvik et al., 2003; Fagan et al., 2004; Wang et al., 2008; Economou et al., 2009) have demonstrated that higher concentrations of $\mathrm{CO}_{2}$ extend the microbiological shelf-life of fresh seafood. However, high concentrations of $\mathrm{CO}_{2}$ can also lead to quality loss.

Salmon spoilage is multifaceted and one of the main factors causing spoilage is the growth of microorganisms (Rasmussen et al., 2002). In MAP preserved salmon, $\mathrm{O}_{2}$ levels and temperature are lower than ambient conditions and these different environments have an impact on the growth of microorganisms. Beside microbiological growth, other chemical indexes can reflect the spoilage level or freshness of Atlantic salmon. For example, total volatile basic nitrogen (TVB-N) (Dhaouadi et al., 2007) and trimethylamine (TMA) have been used for this purpose (Gökoğlu et al., 2004; Erkan and Özden, 2008). TVB-N is an indicator of total nitrogen and during the storage of salmon, the reduction of trimethylamine oxide (TMAO) results in the production of trimethylamine (TMA) (Pena-Pereira et al., 2010). The measurement of TVB-N and TMA has been employed as spoilage indicators for decades and the ratio of TVB-N to TMA (TVB-N/TMA) has been an index of seafood freshness (Mitsubayashi et al., 2004; Howgate, 2010).

Nisin is a well-known bacteriocin that inhibits the growth of gram-positive bacteria and is generally recognized as safe (GRAS) as a food preservative (de Arauz et al., 2009). Researchers have confirmed that nisin (Jofré et al., 2008; Lu et al., 2010; Shirazinejad et al., 2010) and MAP (Raju et al., 2003; Economou et al., 2009; Tsironi et al., 2010; López - Mendoza et al., 2007,) can extend the shelf life of seafood when used individually. However, little 
has been published on combining MAP with nisin to extend the shelf life of fresh Atlantic salmon. Therefore the objective of this research was to determine the effect of nisin combined with MAP on Atlantic salmon shelf life.

\section{Material and Methods}

\subsection{Salmon}

Fresh, sliced farm-raised Atlantic salmon fillets were transported on ice (2:1 ice:salmon ratio)to the laboratory. Salmon was purchased as skinless and boneless fillets from a local grocery store and held under super-chilled conditions $\left(-4 \pm 2^{\circ} \mathrm{C}\right.$ ) until experiments (up to 3 days). Frozen fillets were thawed at $4 \pm 2^{\circ} \mathrm{C}$ for 12 hours. These fillets were cut into portions of approximately $150 \mathrm{~g}$ and then further cut a $25 \mathrm{~g}$ portion and a $10 \mathrm{~g}$ portion of the $150 \mathrm{~g}$ fillet. Thirty nine portions of $150 \mathrm{~g}$ Atlantic salmon samples were prepared and 3 were tested immediately. Processing and packaging procedures were conducted under strict hygienic conditions.

\subsection{Nisin Activity}

Commercial nisin (Nisaplin $®, 10^{6} \mathrm{IU} / \mathrm{g}$ ) was purchased from the manufacturer (Danisco, New Century, KS, USA). Nisaplin ${ }^{\circledR}$ activity was determined in triplicate using a zone of inhibition assay. Nisaplin ${ }^{\circledR}$ sample was diluted 1:500 in sterile water, then a series of two-fold dilutions were tested against Lactobacillus plantarum ATCC 14917 by spotting $10 \mu \mathrm{L}$ of each dilution on the surface of the MRS agar medium seeded uniformly with the suspension of $L$. plantarum. After $48 \mathrm{~h}$ incubation at $37^{\circ} \mathrm{C}$ under $5 \% \mathrm{CO}_{2}$, the plates were examined for inhibition zones. The activity of nisin in Arbitrary Units per $\mathrm{mL}(\mathrm{AU} / \mathrm{mL})$ was expressed as the reciprocal of the highest dilution showing a clear inhibition zone for each triplicate sample. The activity of nisin was expressed in AU/mg based on the weight of the nisin compounds used in serial dilution. Stock nisin $\left(10^{6} \mathrm{IU} / \mathrm{mL}\right.$ solution was then prepared by dissolving Nisaplin® in sterile water.

\subsection{Modified Atmosphere Packaging}

Final gas mixture ratios in packages were $19 \% \mathrm{CO}_{2}: 70 \% \mathrm{~N}_{2}: 11 \% \mathrm{O}_{2}$ and $38 \% \mathrm{CO}_{2}: 51 \% \mathrm{~N}_{2}: 11 \% \mathrm{O}_{2}$. Previous researchers have tested 60:40 $\mathrm{CO}_{2}: \mathrm{N}_{2}$ ratios and studies from our group with other meat types found lower $\mathrm{CO}_{2}$ with $\mathrm{N}_{2}$ and $\mathrm{O}_{2}$ mixtures were successful in extending shelf life (Naas et al., 2013; Kalleda et al., 2013).Three salmon portions (10, 25 and $115 \mathrm{~g}$ ) were placed in foam trays (C976 Sealed Air Cryovac, Duncan, SC) $(83 / 4 * 63 / 4 * 15 / 8$ "). The nisin solution was spread on the surface of fillets using a sterile spreader to obtain a final nisin concentration of $400 \mathrm{IU} / \mathrm{g}$. The six MAP -nisin combination treatments were; air, 19:70:11\% $\mathrm{CO}_{2}: \mathrm{N}_{2}: \mathrm{O}_{2}$ or $38: 51: 11 \% \mathrm{CO}_{2}: \mathrm{N}_{2}: \mathrm{O}_{2}$ each either without or with $400 \mathrm{IU} / \mathrm{g}$ nisin. A Ross JrTM preformed tray MAP machine (Model No. S-3180, Robert Reiser \& Co. Inc., Canton, MA 02021) was used for packaging all salmon. Gases used in the package were pure mixtures of $\mathrm{CO}_{2}, \mathrm{O}_{2}$ and $\mathrm{N}_{2}$ (National Specialty Gases, Durham, NC 27713). A vacuum pressure of $150 \mathrm{mbar}$, gas pressure of $765 \mathrm{mbar}$, seal time of $2.1 \mathrm{sec}$, knife temperature of $143^{\circ} \mathrm{C}$ and seal temperature of $141^{\circ} \mathrm{C}$ were pre-set on the MAP machine. The trays were sealed using lid stock film (Lid 1050) (18.5"wide) to achieve a gas:product ratio of 5:1. All samples were refrigerated $\left(2 \pm 4^{\circ} \mathrm{C} \mathrm{C}\right)$ until the analyses. At the same time, 7 empty packages were also sealed with the 3 gas mixtures and stored in the same environment as salmon samples to monitor the gas composition of empty packages.

\subsection{Analyses - Headspace Gas Analysis}

There were 4 major analyses (headspace gas analyses, microbiologic enumeration, TVB-N titration test, sensory testing) employed to evaluate freshness of salmon samples. All analyses were conducted on samples from each of the 6 treatments as described in Table 1 on days $0,2,4,7$ and 10, except for package headspace gas mixtures which were taken on days 0,2 and 4 . The gas mixture in the headspace of an airtight food package was monitored to determine how gas composition changed relative to the spoilage of the salmon. A gas chromatograph (series 200, Gow-Mac Inst.Co., Bethlehem, PA) fitted with CTR-1 gas analysis column (catalog no.8700, Alltech, Sanjose, CA) and TCD (thermal conductivity detector) was used to determine the package headspace gases $\left(\mathrm{O}_{2}, \mathrm{CO}_{2}, \mathrm{~N}_{2}\right)$. An integrator (Hewlett Packard, Wilmington, DE) was used to plot chromatograms and calculate gas percentages from peak areas. A $0.05 \mathrm{~mL}$ package headspace gas sample was analyzed at each sampling interval by injecting a needle (syringe type) through a gas-tight septum placed onto the package film surface. The chromatograph was calibrated using standardized gas mixtures verified by manufacturer (Air Products and Chemicals Inc., Allentown, PA).

\subsection{Microbiological Enumeration}

Twenty-five g portion of fish samples were aseptically removed from trays, placed in sterile stomacher bags (model 400, 6041/STR, Seward Limited, London, UK) and homogenized for $2 \mathrm{~min}$ at $230 \mathrm{rpm}$ in a laboratory blender (Model 400, Seward ${ }^{\mathrm{TM}}$, FL, USA 33330) containing pre-added $225 \mathrm{~mL}$ pre-chilled sterile peptone-physiological saline solution $(0.1 \%$ peptone $+0.85 \% \mathrm{NaCl})\left(\mathrm{Difco}^{\mathrm{TM}}\right.$, Bactopeptone, Becton, Dickison 
\& Company, MD, USA 21152). Then decimal serial dilutions were prepared from this homogenate in the same chilled sterile diluent. Culture medium for aerobic microorganisms was Plate Count Agar (PCA) (Difco ${ }^{\mathrm{TM}}$, Bactopeptone, Becton, Dickison \& Company, MD, USA 21152). The plates were incubated for $48 \mathrm{~h}$ at $37^{\circ} \mathrm{C}$ and the population of psychrotrophic bacteria was determined by a spread plate counting method with PCA with $1 \%$ $\mathrm{NaCl}$ and incubated at $4{ }^{\circ} \mathrm{C}$ for 7 days. For estimation of potential lactic acid bacteria (LAB), diluted samples were plated on deMan, Rogosa, and Sharpe (MRS) agar and incubated at $37^{\circ} \mathrm{C}$ for $72 \mathrm{~h}$ in a $\mathrm{CO}_{2}$ incubator with a continuous $\mathrm{CO}_{2}$ flow. (Difco ${ }^{\mathrm{TM}}$, Bactopeptone, Becton, Dickinson \& Company, MD, USA 21152) Prior to data analyses of microbiological data, bacterial populations were converted to logarithmic values (CFU/g).

\subsection{Total Volatile Basic Nitrogen}

Total volatile basic nitrogen (TVB-N) tests were prepared by homogenizing $10 \mathrm{~g}$ of fish from trays with $100 \mathrm{ml}$ water in a laboratory blender (Model 400, Seward ${ }^{\mathrm{TM}}$, FL, USA 33330) for $1 \mathrm{~min}$ at $230 \mathrm{rpm}$. Then the salmon-water mixture was centrifuged at $3000 \mathrm{rpm}$ for $5 \mathrm{~min}$ with the centrifuge at 10,000 x g (J-26 XPI, Beckman Coulter, Inc., CA, USA 92821). $10 \mathrm{ml}$ of the supernatant was placed into a distillation tube, followed by $10 \mathrm{~mL}$ of $1 \%(\mathrm{w} / \mathrm{v})$ magnesium oxide suspension. Vacuum-distillation was conducted using a vertical distillation unit (Model RV 10 digital, IKA ${ }^{\circledR}$ Works, Inc., NC, USA 28405) and the distillate was placed into $20 \mathrm{~mL}$ of $2 \%(\mathrm{v} / \mathrm{v})$ aqueous boric acid solution with the 7-8 drops of indicator solution. After five minutes, the distillation was ended and titrated. The titration was conducted using $0.005 \mathrm{~mol} / \mathrm{L}$ sulphuric acid solution. The indicator solution was a mixture of $0.2 \%$ methyl red ethanol solution and $0.1 \%$ methylene blue solution added immediately before titration. The titration endpoint was a color change from green to blue/purple.

\subsection{Sensory Test}

All the assessors were trained using pre-spoiled salmon series. 5 samples were prepared for each of 7 days of training and held at $20^{\circ} \mathrm{C}$ for different time periods to accelerate spoilage. 3 terms (general appearance, color, and odor) were used on a 5 point scale for the 5 samples so that assessors agreed on the different levels of salmon spoilage.

At least 7 assessors were involved in each day's sensory test. On each day of testing, packages were opened and each of the six samples was tested immediately by the trained panel using the 5-point scale. The minimal scoring difference was set at 0.5 . After the grading, panelists were asked to decide if the samples were acceptable or not for consumption.

\subsection{Five-Level Sensory Scale (Modified From Matis, 2016)}

\section{General Appearance:}

level. 1: Firm texture with natural and fresh fish fillet appearance.

level. 2: Slight drip loss and minor reduction on firmness and appearance

level. 3: Soft texture and obvious reduction in appearance

level. 4: Extreme soft texture and critical appearance reduction

level. 5: Totally spoiled salmon texture and appearance

\section{Color:}

level. 1: Flesh-colored salmon tissue with almost no effect of spoilage.

level. 2: Minor change of flesh-colored salmon tissue.

level. 3: Obvious change from flesh-colored to deeper red colors.

level. 4: Extreme change of flesh-color deep red color.

level. 5: Totally spoiled salmon dark red color

\section{Odor:}

level. 1: Flesh seafood-like smell

level. 2: Slight fish odor

level. 3: Obvious change from flesh odor to fishy odor.

level. 4: Strong fishy odor.

level. 5: Completely spoiled fishy odor

\subsection{Statistical Analysis}


All analyses (headspace gas analyses, microbiological enumeration, TVB-N tests and sensory tests) were replicated three times in separate trials with different lots of salmon. Analysis of variance was conducted for each parameter to determine if there was a significant effect $(\mathrm{p} \leq 0.05)$ due to the treatments. When the treatment was determined to be significant for a parameter based on an analysis of variance, the Least Significant Difference (LSD) test was used to separate the means ( $\mathrm{p} \leq 0.05)$ (SAS, Version 9.0, 2004).

\section{Results}

\subsection{Nisin Activity Detection}

An activity level of $1.6 \times 10^{6} \mathrm{AU} / \mathrm{ml}$ was confirmed for the commercial nisin sample. Nisin was first detected from its production by Lactococcus lactis subsp. lactis in 1928, and has become a popular bacteriocin with widespread commercial use (Ross et al., 2002). Nisin effectively inhibits the growth of Gram-positive bacteria, such as Micrococcus, Lactococcus, Staphylococcus, Lactobacillus and Listeria (Arauz et al., 2009). The gram-positive bacteria strain used to determine nisin activity was Lactobacillus plantarum ATCC 14917. The results verified that growth of Lactobacillus plantarum ATCC 14917 can be inhibited by nisin. Also, the commercial nisin sample was found to retain high activity throughout use in the study. Nisin doesn't generally inhibit the growth of gram-negative bacteria, fungi and virus (Arauz et al., 2009). This group of microorganisms can cause spoilage of food products which limits nisin preservation effects. Nisin has been reported to restrict some pathogenic bacterial growth. When L. monocytogenes was inoculated into long-life cottage cheese the number of viable L. monocytogenes cells was reduced by one log with nisin (Ferreira and Lund, 1996). Clostridium sp. can be susceptible to nisin and spore outgrowth of Clostridium $s p$. is more likely to be restricted than vegetative cell growth by nisin (Delves-Broughton, Blackburn, Evans \& Hugenholtz, 1996).

\subsection{Headspace Gas Analyses}

During the storage of empty MAP sealed packages, there was no change in $\mathrm{CO}_{2}$ and $\mathrm{O}_{2}$ percentage concentrations for both $19 \% \mathrm{CO}_{2} / 70 \% \mathrm{~N}_{2} / 11 \% \mathrm{O}_{2}$ and $38 \% \mathrm{CO}_{2} / 51 \% \mathrm{~N}_{2} / 11 \% \mathrm{O}_{2}$ packages $(\mathrm{P}>0.05)$. This result indicates there was an airtight seal and stable gas environment throughout the Atlantic salmon preservation study. Most MAP is formed from one or more of these four materials: polyvinylchloride (PVC), polyethylene terephthalate (PET), polyethylene (PE) and polypropylene (PP), moreover, $\mathrm{PE}$ is usually the major component in a MAP film since it provides the hermetic seal. Polyethylene is also considered for the characteristics of anti-fogging ability, peel ability and the ability to seal under less than optimal conditions (Phillips, 1996).

The technique of sealing modified atmospheres in the polymeric film without further exchange of gasses between inside and outside of the package often generates lower $\mathrm{O}_{2}$ and higher $\mathrm{CO}_{2}$ concentrations compared to atmospheric conditions to extend food shelf life. These conditions can influence the biological activity (respiration, enzymatic reactions, and microbial growth) within the package which can, in turn, inhibit spoilage (Zhao et al., 1995; Mangaraj et al., 2009).

Initial $\mathrm{O}_{2}$ concentration ranged from about $11 \%$ in MAP packages to $21 \%$ for air packages (Table 1). On Day 2, salmon samples packaged in the air with and without nisin had similar $\mathrm{O}_{2}$ concentrations ( $\left.p>0.05\right)$, however, by Day 4 , there was a significant difference $(\mathrm{p} \leq 0.05)$ of the oxygen level between air/nisin and air/no nisin. Also, the $38 \% \mathrm{CO}_{2} \mathrm{MAP}$ treatment inhibited $\mathrm{O}_{2}$ consumption compared to the $19 \% \mathrm{CO}_{2} \mathrm{MAP}(\mathrm{p} \leq 0.05)$ at day 2 . Thus as $\mathrm{CO}_{2}$ concentration increased, the $\mathrm{O}_{2}$ consumption rate of microorganisms present on salmon decreased at early sampling times. This implies that the microorganism's respiration rate was slowed with the increase in $\mathrm{CO}_{2}$ Similar to the contrast between air/nisin and air/no nisin treatments, the $19 \% \mathrm{CO}_{2}$ package with and without nisin on day 4 also limited the metabolism rate of the microorganisms $(\mathrm{p} \leq 0.05)$. As the primary gas consumed by spoilage microorganisms during growth, reduced oxygen has been recognized as an important factor in MAP. Taylor, Davidson, \& Zhong, (2007) reported commercial nisin samples with similar composition as the one used in the current study [2.5\% pure nisin, $74.4 \%$ sodium chloride, $23.8 \%$ denatured milk solids and $1.7 \%$ moisture $(\mathrm{w} / \mathrm{w})]$ had similar activity $\left(10^{6} \mathrm{IU} / \mathrm{g}\right)$. Nisin limited the growth of spoilage microorganisms and reduced total oxygen consumption in both the present and study by Taylor, Davidson \& Zhong (2007). 
Table 1. The concentration of $\mathrm{O}_{2}$ of farmed Atlantic salmon packaged in different air packages and nisin stored at $2-4{ }^{\circ} \mathrm{C}$

\begin{tabular}{lccc}
\hline \multirow{2}{*}{ Treatment (package condition) } & \multicolumn{2}{c}{ Day 0 } & \multicolumn{2}{c}{ Day 2 } & \multicolumn{1}{c}{ Day 4 } \\
\cline { 2 - 4 } & \multicolumn{2}{c}{ Percentage of Oxygen package headspace } \\
\hline Air + Nisin(400 IU/g) & $20.60 \pm 0.26 \mathrm{a}$ & $18.08 \pm 0.57 \mathrm{a}$ & $8.92 \pm 0.42 \mathrm{~b}$ \\
Air without nisin (control) & $20.60 \pm 0.26 \mathrm{a}$ & $17.76 \pm 0.15 \mathrm{a}$ & $5.89 \pm 0.44 \mathrm{~b}$ \\
$38 \% \mathrm{CO}_{2} / 51 \% \mathrm{~N}_{2} / 11 \% \mathrm{O}_{2}+\mathrm{Nisin}(400 \mathrm{IU} / \mathrm{g})$ & $10.75 \pm 0.10 \mathrm{a}$ & $10.45 \pm 0.31 \mathrm{a}$ & $6.95 \pm 0.33 \mathrm{~b}$ \\
$19 \% \mathrm{CO}_{2} / 70 \% \mathrm{~N}_{2} / 11 \% \mathrm{O}_{2}+\mathrm{Nisin}(400 \mathrm{IU} / \mathrm{g})$ & $11.01 \pm 0.18 \mathrm{a}$ & $8.14 \pm 0.28 \mathrm{~b}$ & $6.5 \pm 0.46 \mathrm{~b}$ \\
$38 \% \mathrm{CO}_{2} / 51 \% \mathrm{~N}_{2} / 11 \% \mathrm{O} 2$ without nisin & $10.75 \pm 0.10 \mathrm{a}$ & $9.62 \pm 0.23 \mathrm{a}$ & $6.26 \pm 0.24 \mathrm{~b}$ \\
$19 \% \mathrm{CO}_{2} / 70 \% \mathrm{~N}_{2} / 11 \% \mathrm{O}_{2}$ without nisin & $11.01 \pm 0.18 \mathrm{a}$ & $8.18 \pm 0.39 \mathrm{~b}$ & $4.16 \pm 0.69 \mathrm{cb}$ \\
\hline
\end{tabular}

a-c means within rows with different letters are significantly different $(\mathrm{p} \leq 0.05) . \mathrm{n}=3$

\subsection{Microbiologic Enumeration}

In fresh food product preservation, especially fresh seafood, and meat ingredients, microorganism growth is the primary cause of spoilage (Hozbor et al., 2006). Enumeration of particular microorganisms' groups is important to understand factors affecting spoilage.

\subsubsection{Aerobic Plate Count Cultured at $37{ }^{\circ} \mathrm{C}$}

The average starting population of aerobic microorganisms on salmon was $3.25 \pm 0.06 \log \mathrm{CFU} / \mathrm{g}$. The total aerobic bacteria for the 2 MAP treatments differed from air-packed salmon $(\mathrm{p} \leq 0.05)$ on day 2 (Figure 1 ).

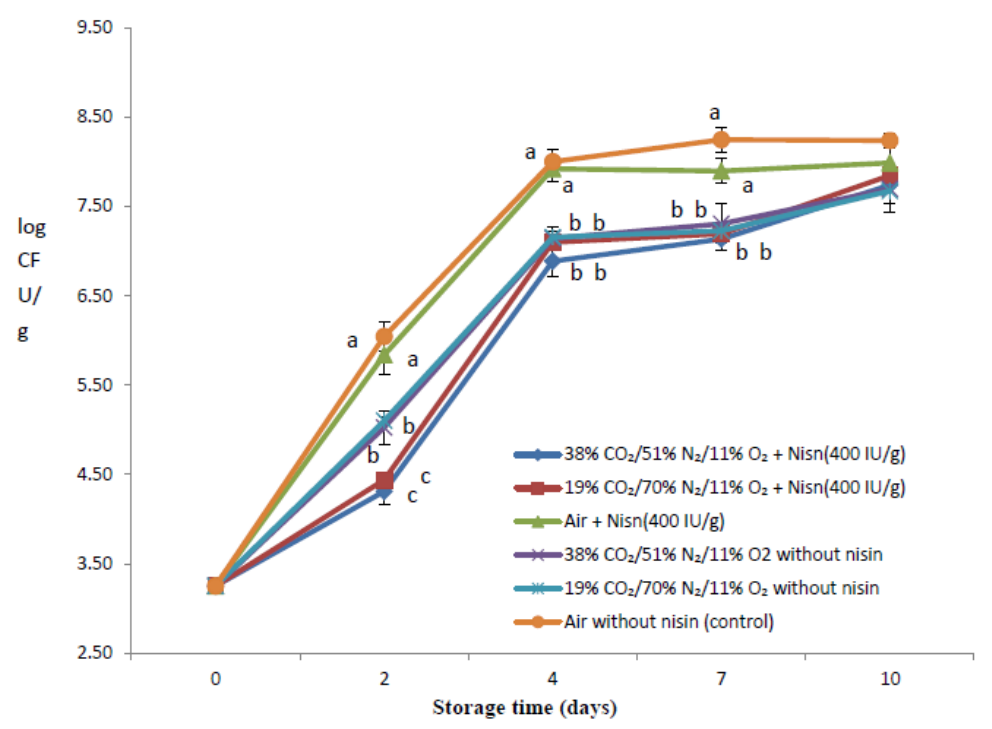

Figure 1. Total aerobic bacterial populations of farmed Atlantic salmon stored at $2-4{ }^{\circ} \mathrm{C}$ packaged in various modified atmosphere packaging with and without nisin $(n=4)$ a-c means with a different letter are significantly different $(\mathrm{p} \leq 0.05)$

Furthermore, the 2 MAP treatments with nisin had a lower population of aerobes on salmon on day 2 compared to the MAP treatments without nisin. No difference in aerobic bacteria population was observed between salmon packaged in $\mathrm{CO}_{2}$ concentrations of $19 \%$ and $38 \%$ ( $\mathrm{p}>0.05$ ). On days 2, 4 and 7 the population of bacteria on salmon packaged in the air was greater than MAP-packaged salmon $(\mathrm{p} \leq 0.05)$. By day 10, MAP salmon treatments had reached $\sim 8 \log \mathrm{CFU} / \mathrm{g}$ aerobic, however, air-packed salmon reached this level by Day 4 . Ibrahim Sallam (2004) used $7 \mathrm{log}$ CFU/g aerobic plate count population as the spoilage indicator in fish products and following this standard, MAP-packaged salmon had approximately a 1-2 day longer shelf life compared to salmon packaged in air.

\subsubsection{Psychrotrophic Bacteria Count}

Similar to aerobic microorganisms, no difference in psychrotrophic bacteria population was observed between 
salmon packaged in $\mathrm{CO}_{2}$ concentrations of $19 \%$ and $38 \%$ (p>0.05) (Figure 2). Air-packaged salmon had higher psychrotrophic bacteria populations (about $1 \log \mathrm{CFU} / \mathrm{g}$ ) than the other four treatments at day $2(\mathrm{p} \leq 0.05)$. Thus, $\mathrm{CO}_{2}$ inhibited the growth of psychrotrophic bacteria while nisin had no observable inhibition of psychrotrophic bacteria $(p>0.05)$. As storage continued, psychrotrophic bacteria population differences due to the various treatments diminished $(\mathrm{p}>0.05)$.

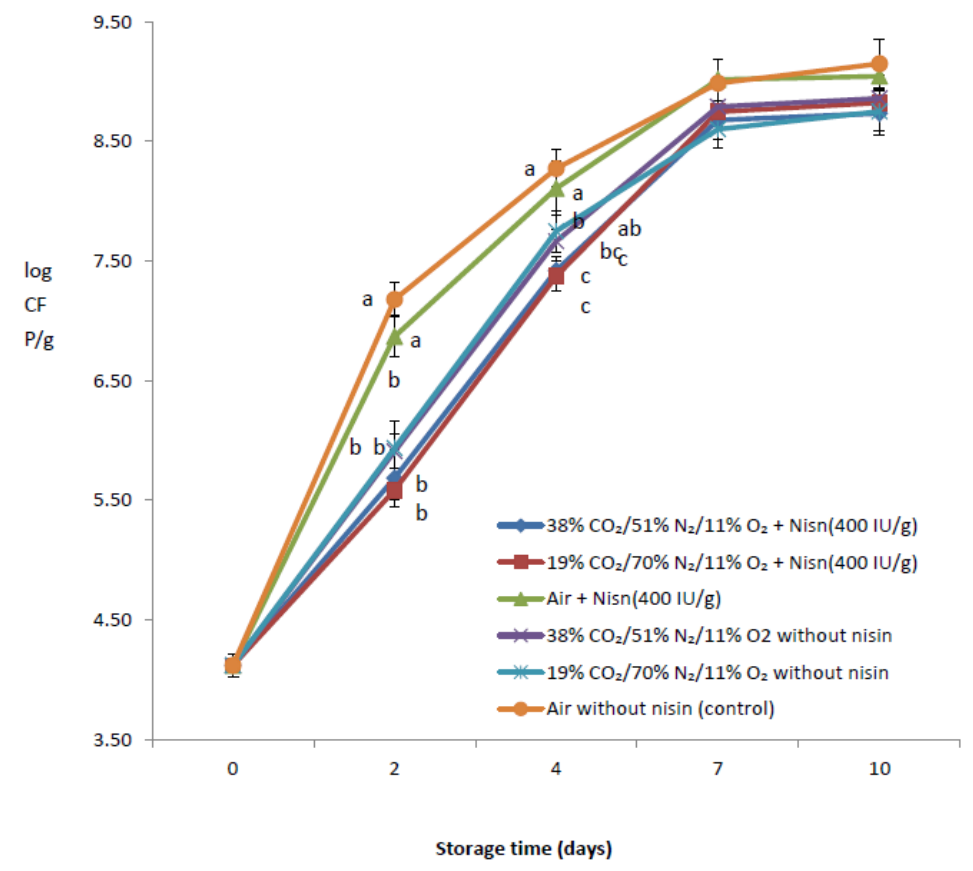

Figure 2. Psychrotrophic bacterial populations of farmed Atlantic salmon stored at $2-4{ }^{\circ} \mathrm{C}$ packaged in various modified atmosphere packaging with and without nisin $(n=6)$. a-c means within rows with a different letter are significantly different $(\mathrm{p} \leq 0.05)$

Due to the storage of fresh fish at refrigerated temperatures, psychrotrophic bacteria dominate the spoilage of refrigerated fish (Sivertsvik et al., 2002). Gram-negative psychrotrophic bacteria often dominate in the spoilage of refrigerated fresh food products and thus may reduce the efficiency for nisin to extend shelf life since nisin alone has a little inhibitory effect on Gram-negative bacteria. Nisin can target vegetative cells acting at the cytoplasmic membrane causing pores resulting in cell degradation (Bauer and Dicks, 2005). However, nisin is usually ineffective against gram-negative bacteria due to the presence of the lipopolysaccharide layer (LPS) (Millette et al., 2004).

\subsubsection{Lactic Acid Bacterial Count}

Initial lactic acid bacteria (LAB) populations were $1.25 \pm 0.17 \log \mathrm{CFU} / \mathrm{g}$ and compared to MAP packaged salmon, air packaged samples without nisin had higher populations at day 2 and 4 than any $\mathrm{CO}_{2}$ packaged salmon ( $\mathrm{p} \leq 0.05$ )(Figure 3). The $38 \% \mathrm{CO}_{2}$ preserved salmon inhibited LAB population compared to $19 \% \mathrm{CO}_{2}$ regardless of nisin application at day 2. As storage continued, LAB population differences due to the various treatments dissipated. Interestingly, there may be a synergistic effect of LAB and nisin on Gram-negative bacteria since LAB has been shown to disrupt the outer Gram-negative membrane (Alakomi et al, 2000), possibly making Gram negative bacteria more susceptible to nisin. 


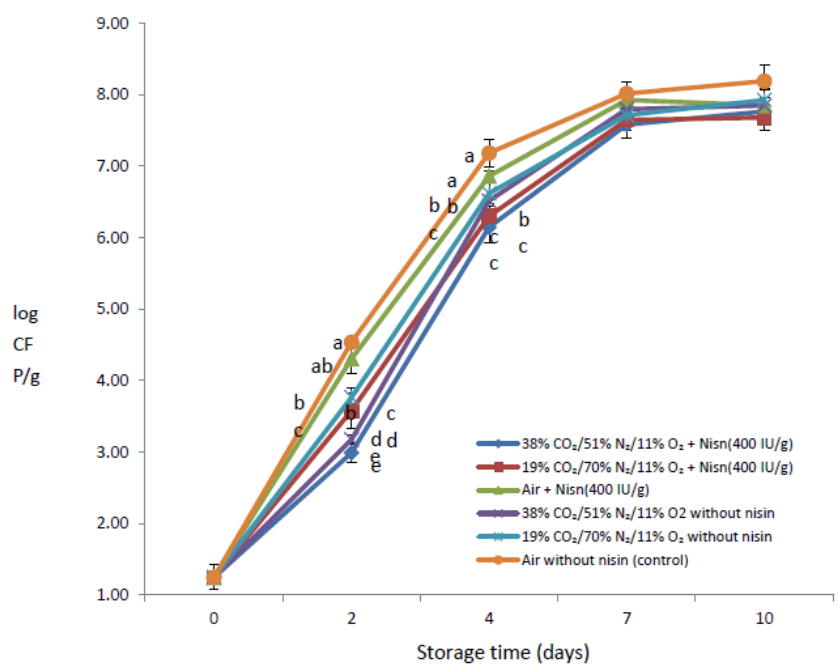

Figure 3. Lactic acid bacterial populations of farmed Atlantic salmon stored at $2-4{ }^{\circ} \mathrm{C}$ packaged in various modified atmosphere packaging with and without nisin $(n=6)$. a-e means within rows with a different letter are significantly different $(\mathrm{p} \leq 0.05)$

\subsubsection{TVB-N Titration Test}

The initial concentration of total volatile basic nitrogen (TVB-N) titration was $2.89 \pm 0.01 \mathrm{mg} / 100 \mathrm{~g}$. On all 4 sampling days, TVB-N concentration was higher in air-packed salmon compared to MAP packed salmon (Figure 4) $(\mathrm{p} \leq 0.05)$. The only difference in TVB-N between air/nisin and air/non-nisin packed salmon was on day 2 $(\mathrm{p} \leq 0.05)$. No significant TVB-N difference was detected between the $4 \mathrm{CO}_{2}$ MAP treatments $(\mathrm{p}>0.05)$. The application of $\mathrm{CO}_{2}$ delayed Atlantic salmon spoilage as determined by TVB-N. A significant difference was detected between the $\mathrm{CO}_{2} \mathrm{MAP}$ and the air packed samples on all four sampling days $(\mathrm{p}<0.05)$. No significant difference in the production of TVB-N was found between the $38 \%$ and $19 \% \mathrm{CO}_{2}(\mathrm{p}>0.05)$. Nisin had no impact on the TVB-N concentration except for air packed samples on day $2(\mathrm{p} \leq 0.05)$. Application of nisin in the aerobic atmosphere has been extensively researched but nisin under anaerobic conditions has not received as much attention. Nisin was not as effective as $\mathrm{CO}_{2}$ headspace in inhibiting the general spoilage of packaged Atlantic salmon. The increase in TVB-N shows a similar trend as the bacterial growth of the psychrotrophic bacteria. Previous research has verified a strong connection between the generation of TVB-N and the spoilage of refrigerated fresh products (Arashisar, Hisar, Kaya \& Yanik, 2004, Ojagh, Rezaei, Razavi, \& Hosseini, 2010)

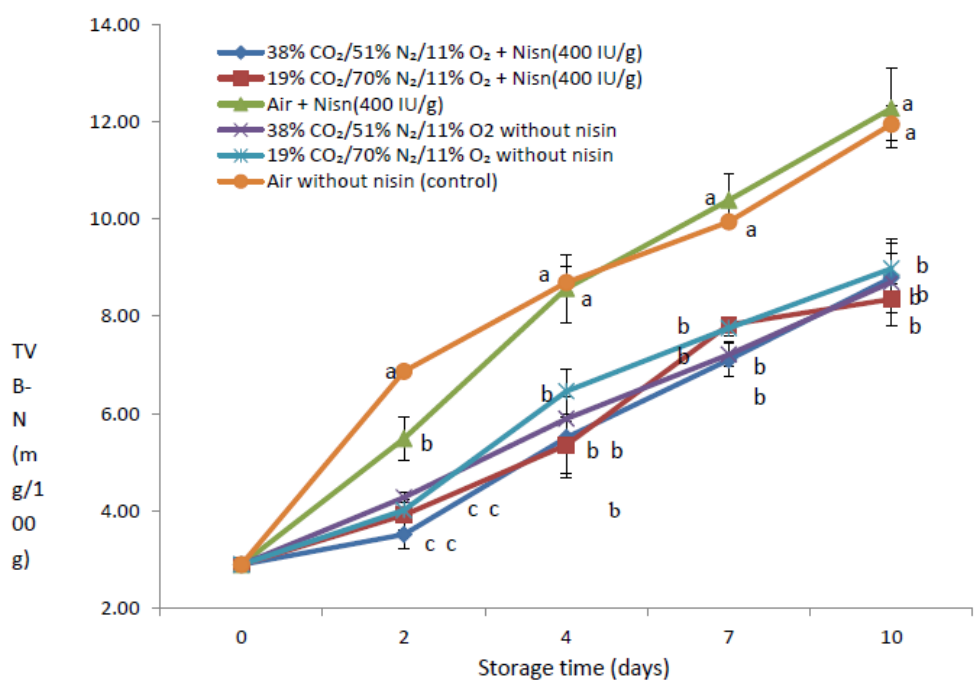

Figure 4. TVB- $\mathrm{N}$ of farmed Atlantic salmon stored at $2-4{ }^{\circ} \mathrm{C}$ packaged in various modified atmosphere packaging with and without nisin $(n=6)$. a-c means within rows with a different letter are significantly different $(\mathrm{p} \leq 0.05)$ 
Lactic acid bacteria are recognized as one of the major spoilage groups in MAP foods and controlling LAB can impact shelf-life. The higher package $\mathrm{CO}_{2}$ concentration resulted in a slower growth of $\mathrm{LAB}(\mathrm{p} \leq 0.05)$. Although $\mathrm{LAB}$ is recognized as a spoilage bacteria that can grow at low oxygen levels, the present of $\mathrm{CO}_{2}$ successfully slowed the growth of LAB in the current experiment. Sivertsvik et al. (2002) concluded that $\mathrm{CO}_{2}$ decreases the growth of microorganism especially aerobic bacteria and that this inhibition could not be explained only by the limited $\mathrm{O}_{2}$ nor the $\mathrm{pH}$ changes caused by the $\mathrm{CO}_{2}$. Other research has revealed that the presence of oxygen can inhibit the growth of LAB (Ibrahim Sallam, 2007). Sivertsvik et al. (2002) theorized that the effect of $\mathrm{CO}_{2}$ on microorganisms could be described by changes in cell membrane function which effect nutrient absorption, the deactivation of enzymes, degradation of membranes and changes in the proteins. The results show that nisin was not as effective as $\mathrm{CO}_{2}$ in limiting the growth of $\mathrm{LAB}$.

\subsection{Sensory Test}

While sensory analysis can be affected by microbiological status, microbial safety is a priority during shipping and storage of fish.. No significant difference $(p>0.05)$ were detected for the first three evaluation terms (appearance, color, and odor) due to the 6 treatments. On the acceptability, a significant difference was observed that air packaged sample without nisin application displayed the lowest acceptable rate on day 4 ( $\mathrm{p} \leq 0.05)$. Thus all the $\mathrm{CO}_{2}$ or nisin -treated Atlantic salmon samples were more acceptable than control salmon samples. Fish tissue usually contains $60-80 \%$ (w/w) water (Ghaly et al., 2010) and the drip loss can cause the major decrease of fresh fish's appearance. The release of water from the fish tissue resulting from microbial growth can reduce the general appearance and overall quality of Atlantic salmon. Alfnes et al. (2006) mentioned the color of salmon is an essential factor of freshness. Ottestad et al. (2011) reported that the color of Atlantic salmon is dependent on the relationship between oxygen and myoglobin. No sensory color difference $(p>0.05)$ was observed in the current study. Inside and surface volatile and non-volatile amines (Bulushi et al., 2009) are the major spoilage amine produced by the blooming of all kinds of microorganisms. Although differences between TVB-N test results were observed, there was no significant difference $(p>0.05)$ in the sensory odor evaluation. However, a difference in salmon acceptability $(\mathrm{p} \leq 0.05)$ was observed between the control (no nisin packaged in air) and the other 5 storage treatments of Atlantic salmon.

\section{Conclusion}

Combining MAP with nisin can impact the spoilage rate of Atlantic salmon, however, little synergistic effect between MAP and nisin were observed in this study. In all three microbiological test methods (aerobic plate count, psychrotrophic bacteria, and $\mathrm{LAB}$ ), the present of $\mathrm{CO}_{2}$ effectively inhibited the growth of these microorganisms. However, the inhibition effectiveness difference between the medium concentration of $\mathrm{CO}_{2}$ (38\%) and low concentration of $\mathrm{CO}_{2}(19 \%)$ was only found in LAB. Furthermore, nisin only significantly inhibited the growth of aerobic microorganisms. $\mathrm{CO}_{2}$ can efficiently limit the spoilage of Atlantic salmon as measured by the TVB-N test but no difference was observed between $38 \%$ and $19 \% \mathrm{CO}_{2}$. The sensory evaluation found no differences in appearance, color, and odor. But more assessors tended to reject the non-nisin and non- $\mathrm{CO}_{2}$ packed samples compared to the other treatments. Modified atmosphere packaging alone may be a more cost-effective than adding nisin to shelf life extension of fresh salmon.

\section{References}

Alakomi, H.L., Skytta, E., Saalrela, M., Mattila-Sandholm, T., Latva-Kala, K. \& Helander, I.M. 2000. Lactic acid permeabilizes Gram-negative bacteria by disrupting the outer membrane. Applied and Environmental Microbiology 66(5), 2001-2005. http://dx.doi: 10.1128/AEM.66.5.2001-2005.2000

Alfnes, F., Guttormsen, A. G., Steine, G., \& Kolstad, K. (2006). Consumers' willingness to pay for the color of salmon: a choice experiment with real economic incentives. American Journal of Agricultural Economics, 88(4), 1050-1061. http://dx.doi.org/10.1111/j.1467-8276.2006.00915.x

Arashisar, Ş., Hisar, O., Kaya M., \& Yanik, T. (2004). Effects of modified atmosphere and vacuum packaging on microbiological and chemical properties of rainbow trout (Oncorhynchus mykiss) fillets. International Journal of Food Microbiology, 97(2), 209-214. http://dx.doi.org/10.1016/j.ijfoodmicro.2004.05.024

Bauer, R., \& Dicks, L. M. T. (2005). Mode of action of lipid II-targeting lantibiotics. International Journal of Food Microbiology, 101(2), 201-216. http://dx.doi.org/10.1016/j.ijfoodmicro.2004.11.007

Bulushi, I. A., Poole, S., Deeth, H. C., \& Dykes, G. (2009). Biogenic amines in fish: roles in intoxication, spoilage, and nitrosamine formation-a review. Critical reviews in Food Science and Nutrition, 49(4), 369-377. http://dx.doi.org/10.1080/10408390802067514

Davies, A. R., (1995). New methods of food preservation. (Chapter 14) In G.W. Gold (ED.) Advances in 
modified-atmosphere packaging (pp. 304-320). Springer US

De Arauz, L. J., Jozala, A. F., Mazzola, P. G., \& Penna, T.C. (2009). Nisin biotechnological production and application: a review. Trends in Food Science \& Technology, 20(3), 146-154. http://dx.doi.org/10.1016/j.tifs.2009.01.056

Delves-Broughton, J., Blackburn, P., Evans, R. J., \& Hugenholtz, J. (1996). Applications of the bacteriocin, nisin. Antonie van Leeuwenhoek, 69(2), 193-202. http://dx.doi.org/10.1007/BF00399424

Devlieghere, F., Debevere, J., \& Van Impe, J. (1998). Effect of dissolved carbon dioxide and temperature on the growth of Lactobacillus sake in modified atmospheres. International Journal of Food Microbiology, 41(3), 231-238. http://hdl.handle.net/1854/LU-348287

Dhaouadi, A., Monser, L., Sadok, S., \& Adhoum, N. (2007). Validation of a flow-injection-gas diffusion method for total volatile basic nitrogen determination in seafood products. Food Chemistry, 103(3), 1049-1053. DOI: http://dx.doi.org/10.1016/j.foodchem.2006.07.066

Erkan, N., \& Özden, Ö. (2008). Quality assessment of whole and gutted sardines (Sardina pilchardus) stored in ice. International Journal of Food Science and Technology, 43(9), 1549-1559. http://dx.doi.org/10.1111/j.1365-2621.2007.01579.x

Ferreira, M., \& Lund, B. M. (1996). The effect of nisin on Listeria monocytogenes in culture medium and long - life cottage cheese. Letters in Applied Microbiology, 22(6), 433-438.

http://dx.doi.org/10.1111/j.1472-765X.1996.tb01197.x

Ghaly, A. E., Dave, D., Budge, S., \& Brooks, M. S. (2010). Fish spoilage mechanisms and preservation techniques: review. American Journal of Applied Sciences, 7(7), 859-863. http://dx.doi.org/10.3844/ajassp.2010.859.877

Gökoğlu, N., Cengız, E., \& Yerlıkaya, P. (2004). Determination of the shelf life of marinated sardine (Sardina pilchardus) stored at $4^{\circ}$ C. Food Control, 15(1), 1-4. http://dx.doi.org/10.1016/S0956-7135(02)00149-4

Hozbor, M. C., Saiz, A. I., Yeannes, M. I., \& Fritz, R. (2006). Microbiological changes and its correlation with quality indices during aerobic iced storage of sea salmon (Pseudopercis semifasciata). LWT-Food Science and Technology, 39(2), 99-104. http://dx.doi.org/10.1016/j.lwt.2004.12.008

Ibrahim Sallam, K. (2007). Antimicrobial and antioxidant effects of sodium acetate, sodium lactate, and sodium citrate in refrigerated sliced salmon. Food control, 18(5), 566-575. http://dx.doi.org/10.1016/j.foodcont.2006.02.002

Jayasingh, P., Cornforth, D. P., Brennand, C. P., Carpenter, C., \& Whittier, D. R. (2002). Sensory evaluation of ground beef stored in high - oxygen modified atmosphere packaging. Journal of Food Science, 67(9), 3493-3496. http://dx.doi.org/10.1111/j.1365-2621.2002.tb09611.x

Kalleda, R. K., Han, I., Toler, J., Chen, F., Kim, H. J., \& Dawson, P. L. (2013). Shlef life extension of shrimp (white) using modified atmosphere packaging. Polish Journal of Food and Nutrition Sciences, 63(2), 87-94. http://dx.doi.org/10.2478/v10222-012-0071-7.

López-Mendoza, M. C., Ruiz, P., \& Mata, C. M. (2007). Combined effects of nisin, lactic acid and modified atmosphere packaging on the survival of Listeria monocytogenes in raw ground pork. International Journal of Food Science and Technology, 42(5), 562-566. http://dx.doi.org/10.1111/j.1365-2621.2006.01275.x.

Mangaraj, S., Goswami, T. K., \& Mahajan, P. V. (2009). Applications of plastic films for modified atmosphere packaging of fruits and vegetables: a review. Food Engineering Reviews, 1(2), 133-158. http://dx.doi.org/10.1007/s12393-009-9007-3

Matis. (2016). Chill fish from catch to consumer. Chill-on (EU Integrated project), Chill add-on (Icelandic project) and Thermal modelling of chilling and transport of fish (Icelandic project) and also on regulations from The Icelandic Food and Veterinary Authority. Vínlandsleið 12, 113 Reykjavík. http://www.kaeligatt.is/english. Accessed 11-10-16

McMillin, K. W. (2008). Where is MAP going? A review and future potential of modified atmosphere packaging for meat. Meat Science, 80(1), 43-65. http://dx.doi.org/10.1016/j.meatsci.2008.05.028

Millette, M., Smoragiewicz, W., \& Lacroix, M. (2004) Antimicrobial potential of immobilized Lactococcus lactis subsp. lactis ATCC 11454 against selected bacteria. Journal of Food Protection, 67(6), 1184-1189. 
Ojagh, S. M., Rezaei, M., Razavi, S. H., \& Hosseini, S. M. H (2010). Effect of chitosan coatings enriched with cinnamon oil on the quality of refrigerated rainbow trout. Food Chemistry, 120(1), 193-198. http://dx.doi.org/10.1016/j.foodchem.2009.10.006

Naas, H. Martinez-Dawson, R., Hand I., \& Dawson, P. L. (2013). Effect of combining nisin with modified atmosphere packaging on inhibition of Listeria monocytogenes in ready-to-eat turkey bologna. Poultry Science, 92, 1930-1935. http://dx.doi.org/10.3382/ps.2012-02141

Ottestad, S., Sørheim, O., Heia, K., Skaret, J., \& Wold, J. P. (2011). Effects of storage atmosphere and heme state on the color and visible reflectance spectra of salmon (Salmo salar) fillets. Journal of Agricultural and Food Chemistry, 59(14), 7825-7831. http://dx.doi.org/10.1021/jf201150x

Phillips, C. A. (1996). Review: modified atmosphere packaging and its effects on the microbiological quality and safety of produce. International Journal of Food Science and Technology, 31(6), 463-479. http://dx.doi.org/10.1046/j.1365-2621.1996.00369.x

Raju, C. V., Shamasundar, B. A., \& Udupa, K. S. (2003). The use of nisin as a preservative in fish sausage stored at ambient $\left(28 \pm 2{ }^{\circ} \mathrm{C}\right)$ and refrigerated $\left(6 \pm 2{ }^{\circ} \mathrm{C}\right)$ temperatures. International Journal of Food Science and Technology, 38(2), 171-185. http://dx.doi.org/10.1046/j.1365-2621.2003.00663.x

Rasmussen, S. K. J., Ross, T., Olley, J., \& McMeekin, T. (2002). A process risk model for the shelf life of Atlantic salmon fillets. International Journal of Food Microbiology, 73(1), 47-60. http://dx.doi.org/10.1016/S0168-1605(01)00687-0

Ring $\varnothing$, E., \& Gatesoupe, F. J. (1998). Lactic acid bacteria in fish: a review. Aquaculture, 160(3), 177-203.

Scott, V. N., \& Taylor, S. L. (1981). Temperature, pH, and spore load effects on the ability of nisin to prevent the outgrowth of Clostridium botulinum spores. Journal of Food Science, 46(1), 121-126. http://dx.doi.org/10.1111/j.1365-2621.1981.tb14544.x

Sivertsvik, M., Jeksrud, W. K., \& Rosnes, J. T. (2002). A review of modified atmosphere packaging of fish and fishery products-significance of microbial growth, activities and safety. International Journal of Food Science and Technology, 37(2), 107-127. http://dx.doi.org/10.1046/j.1365-2621.2002.00548.x

Sivertsvik, M., Rosnes, J. T., \& Kleiberg, G. H. (2003). Effect of modified atmosphere packaging and superchilled storage on the microbial and sensory quality of Atlantic salmon (Salmo salar) fillets. Journal of Food Science, 68(4), 1467-1472. http://dx.doi.org/10.1111/j.1365-2621.2003.tb09668.x

Taylor, T. M., Davidson, P. M., \& Zhong, Q. (2007). Extraction of nisin from a 2.5\% commercial nisin product using methanol and ethanol solutions. Journal of Food Protection, 70(5), 1272-1276.

Zhao, Y., Wells, J. H., \& McMillin, K. W. (1995). Dynamic changes of headspace gases in $\mathrm{CO}_{2}$ and $\mathrm{N}_{2}$ packaged fresh beef. Journal of Food Science, 60(3), 571-575.

\section{Copyrights}

Copyright for this article is retained by the author(s), with first publication rights granted to the journal.

This is an open-access article distributed under the terms and conditions of the Creative Commons Attribution license (http://creativecommons.org/licenses/by/4.0/). 